\title{
O DNA da Ciência \& Saúde Coletiva
}

Ao completar seus 25 anos com esta Edição Comemorativa, a Revista Ciência \& Saúde Coletiva destaca para o leitor, dentre muitos outros, quatro aspectos que a tornam relevante, sem esconder suas fragilidades e desafios para o futuro.

Em primeiro lugar, está sua pertença à Associação Brasileira de Saúde Coletiva (Abrasco) cuja história de 40 anos se confunde com a construção do SUS. Isso está no DNA da Revista e marca seu crescimento, desenvolvimento e compromisso. A partir dessa sintonia, observa-se que seu foco principal é a política de saúde.

Em segundo lugar, desde sua primeira edição, em setembro de 1996, em sua coleção de artigos, a Revista Ciência \& Saúde Coletiva acompanha a formulação, a implantação, a implementação e a avaliação das ações do SUS. Por isso, pode-se afirmar que ela vem contribuindo para o aprimoramento da reflexão sobre o setor. Silva et al. ${ }^{1}$ destacam este periódico como um grande pilar para a constituição do campo² da Saúde Coletiva.

Acrescenta-se que ela tem cumprido outro papel também muito importante hoje para o país, que é o de incrementar a reflexão mundial sobre políticas de saúde. Por ser a revista brasileira do campo que mais publica sobre o tema, ela se sente contemplada no Relatório de Atividades da CAPES referente à Área de Saúde Coletiva de 2017, que compara os triênios de 2003-2005 e de 2013-2015, no portal SJR: "A produção brasileira em Política de Saúde passou da $26^{a}$ para a $7^{a}$ posição na produção de artigos científicos no mundo, representando 3,2\% do total no triênio 2013-2015. A participação da produção nacional em Saúde Pública, Saúde Ambiental, Saúde Ocupacional e em Epidemiologia em relação à produção mundial dobrou no período, enquanto a da área de Ciências Sociais em Saúde aumentou sete vezes"3.

Um terceiro aspecto muito interessante que o acervo da Revista sugere é o do tratamento epistemológico do fenômeno saúde/doença. Boa parte dos textos articula conhecimentos de ciências básicas, de saúde coletiva e de clínica. Esse comportamento poderia ser execrado anos atrás, quando era importante distinguir o que era ou não era saúde coletiva, num momento inicial de construção do campo. No entanto, no mundo contemporâneo, como lembram Wallerstein ${ }^{4}$ e Giddens e Turner ${ }^{5}$, a distinção de matérias e áreas tem mais o sentido de reserva de mercado disciplinar do que de orientação da produção de conhecimentos frente a realidades complexas e que exigem a colaboração teórica e multimétodos.

Em quarto lugar, uma observação sobre os métodos científicos utilizados pelos autores. No decorrer do tempo, como ocorre na maioria dos periódicos do setor, observa-se o predomínio das abordagens epidemiológicas que usam métodos quantitativos, em detrimento dos estudos qualitativos. Porém, existe uma boa parcela do acervo da Revista que apresenta trabalhos multimétodos e articula análises de dados estatísticos e aprofundamento compreensivo dos problemas. Como ocorre no campo científico do mundo inteiro ${ }^{4,5}$, as principais críticas em relação ao acervo comemorativo se referem ao insuficiente aprofundamento metodológico e analítico tanto dos estudos quantitativos como dos qualitativos. Portanto, essa questão continua a ser relevante para editores e pareceristas que analisam os originais a serem publicados. $\mathrm{O}$ desafio maior, porém, é dos professores, pesquisadores e orientadores que formam os autores. A publicação de um artigo é a última etapa do processo científico e depende da qualidade dos trabalhos e do grau de cientificidade que a comunidade acadêmica apresenta.

Como qualquer ação humana, a Revista Ciência \& Saúde Coletiva permanentemente vivencia problemas e obstáculos: foi assim durante 25 anos. Sua disposição é de enfrentá-los e cada vez mais oferecer aos colaboradores e aos leitores um acervo de pensamento que os ajude a serem autores e atores na construção científica do campo e do SUS.

Maria Cecília de Souza Minayo (https://orcid.org/0000-0001-6187-9301) ${ }^{1}$

Romeu Gomes (https://orcid.org/0000-0003-3100-8091) ${ }^{2}$

Antônio Augusto Moura da Silva (https://orcid.org/0000-0003-4968-5138) ${ }^{3}$

${ }^{1}$ Escola Nacional de Saúde Pública Sérgio Arouca, Fiocruz. Rio de Janeiro RJ Brasil.

${ }^{2}$ Instituto Fernandes Figueira, Fiocruz. Rio de Janeiro RJ Brasil.

${ }^{3}$ Departamento de Saúde Pública, Universidade Federal do Maranhão. São Luís MA Brasil.

\section{Referências}

1. Silva LV, Esperidião MA, Silveira AS, Paim JS. A construção do campo da Saúde Coletiva e as políticas de saúde - Contribuições da Revista Ciência \& Saúde Coletiva. Cien Saude Colet 2020; 25(12):2013-2022.

2. Bourdieu P. O poder simbólico. Rio de Janeiro: Bertrand Brasil; 2012.

3. Coordenação de Aperfeiçoamento de Pessoal de Nível Superior (CAPES). CAPES divulga resultado final da Avaliação Quadrienal 2017. [acessado 2020 Ago 24]. Disponível em https://www.capes.gov.br/36-noticias/8558-avaliacao-da-capes-apontacrescimento-da-pos-graduacao-brasileira

4. Wallerstein I. Análise dos sistemas mundiais. In: Giddens A, Turner J, organizadores. Teoria social hoje. São Paulo: Editora Unesp; 1999. p. 447-70.

5. Giddens A, Turner JH. Apresentação. In: Giddens A, Turner JH, organizadores. Teoria social hoje. São Paulo: Editora Unesp; 1999. p. 8-21. 